Copyright (C) 2018 by Academic Publishing House Researcher

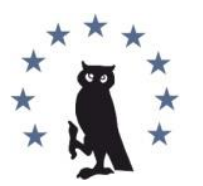

Published in the Russian Federation

European Researcher. Series A

Has been issued since 2010.

ISSN 2219-8229

E-ISSN 2224-0136

2018, 9(2): 126-131

DOI: 10.13187/er.2018.2.126

www.erjournal.ru

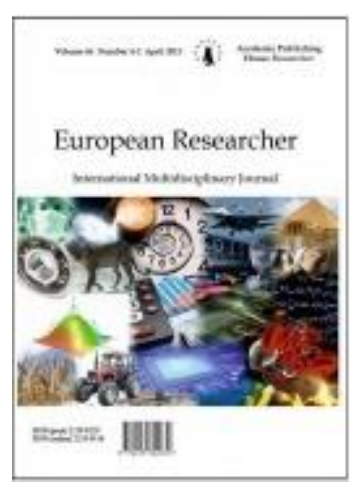

\title{
Turkologists and the Aspect Category of Turkic Languages in Diachrony
}

\author{
Fazira A. Kakzhanova a, *
}

a Buketov Karaganda State University, Kazakhstan

\begin{abstract}
This article is dedicated to the aspect category of the Turkic languages in diachrony, including the Kazakh language. The aspect category is not only the problem of the Kazakh language, but also it is the problem of Turkic languages. The aspect category is the most important category of the verb it determines propositions of sentences. A sentence is thought. In spite of this, language has objectively all prerequisites for having this category, the Kazakh language has no still the aspect category in the morphology of a verb.

Our task is to trace the history of the aspectological thought in Turkic studies to find answers to the questions was or was not the aspect category in diachrony?

Kazakh language as the representative of Turkic languages has several periods of its development: the Ancient period, the Eurocentrism, the Soviet and the new periods. The Eurocentrism period was the beginning of establishing the Kazakh language as a subject. Such a specific question as the aspect category was appeared later in the Soviet period of developing of Turkic languages.

Keywords: diachrony, aspect, tense, mood, the plane of expression, analytical expression, the Soviet period.

\section{Introduction}

The Turkic languages belong to the Altai family and they are the most widespread language family, which are found in all continents of the world. Speakers of these languages played a special role in changing the geographic landscape of many countries, having a serious impact on the course of world history in ancient time. Therefore, it is not surprising that these languages are heard in all parts of Eurasia and other continents. They did not only influence on the geopolitics and geographic location of many ethnic groups, but also to their national consciousness through culture.

An invaluable contribution to the formation and development of the Turkic languages, including the Kazakh language, was made by the brilliant representatives of the OrientalistTurkologist school: N.I. Ilminsky, the pioneer of the study of the Kazakh language, his work in the field of vocabulary formed the basis for the writing of bilingual dictionaries; V.V. Radlov, his 'Experience of the Dictionary of the Turkic dialects' in four volumes; P. Melioransky, his textbook 'Brief grammar of the Kazakh-Kirghiz language' in two parts, etc. Their scientific works enriched the linguistics of the Turkic languages, including the Kazakh language with evidence base and factual materials in the field of vocabulary, phonetics, grammar and writing.
\end{abstract}

\footnotetext{
${ }^{*}$ Corresponding author

E-mail addresses: fazira11 @ mail.ru (F.A. Kakzhanova)
} 
They paid attention to the general components of the Turkic languages as grammar, lexis, and phonetics, they did not deal with a specific problem as the aspect category, besides P.Melioransky, who wrote about the aspect of the Kazakh gerunds, and then he developed it. They helped the formation of the Kazakh language.

The aspect theory was developed during the Soviet period. An invaluable contribution to the study of the Turkic languages was made by well-known turkologists: N.A. Baskakov, A.N. Kononov, B.A. Serebrennikov, I.I. Meschaninov, N.K. Dmitriyev, D.M. Nasilov, A.N.Tikhonov, A. Shcherbak, L.N. Kharitonov, V.A. Bogoroditsky, N.P. Dyrenkov, L. Johanson and many others.

We express our gratitude for their discoveries and deep judgments in various areas of Turkic linguistics.

\section{Materials and methods}

Theoretical materials are the materials of the enumerated turkologists above. The general, semantic, pragmatic analyses of theoretical studies with critical thinking were used.

\section{Discussion}

The aspect category began to develop from the end of the $16^{\text {th }}$ century, but as a scientific trend it was later created by Slavic linguists. This theory was created on the basis of the planes of the aspect expression of the Slavic languages.

There are many reasons of denying of the aspect category in the Kazakh language (belongs to the Turkic languages) and one of them is that linguists of the Kazakh language fully accepted the notional category apparatus of the aspect theory created on the basis of the planes of expressions of the Slavic languages. In spite of that these languages belong to synthetic languages, they represent two branches of it: agglutinative and inflectional, it means that their affixes function differently, sooner or later this would lead to the negation of the category of aspect (Kakzhanova,2015) and there were some inaccuracies in this theory.

- The first thesis that there is no the aspect category in the Turkic languages.

The problems of the verbal aspect in Turkic languages belong to the number of the most difficult problems of Turkology, which have not yet found their final solution. In foreign Turkology, this problem has never been specially raised. This was promoted by the widely held opinion abroad that the verbal aspect is not inherent at all in so-called Ural-Altaic languages (Serebrennikov, 1958).

There is no unity in understanding of the aspect category, it was not reached in the special discussion devoted to the aspect problem in Alma-Ata in 1956 at a special coordination meeting of the Turkologists, where two directions of development of the aspect category in the Turkic languages were noted. Some believed that the grammatical category of the verbal aspect in the form that had the Slavic languages was absent in the Turkic languages, while others believed that the aspect category existed, noting the peculiarities of the category of aspect in the Turkic languages.

The Turkic languages have the same matrix, synergy, structures, but there are some divergence within matrix. 'This discussion clearly showed that the aspect is a phenomenon that had a different development in Turkic languages, that forms united under the general name 'aspect' often had different meanings in different languages, different character and different uses' (Yuldashev,1955) .

Denying the aspect category in Turkic languages in general, Nasilov V.M (1947). wrote 'nevertheless, the problem of the aspect for the Turkic languages should not be ruled out altogether, but its solution is apparently possible only through a consistent and detailed analysis of the temporal and aspectual forms of verbs, Aktionsarts of the verbal action through the description of aspectual contexts and situations, semantic verbal groups and others.

There is not an aspect category in Turkish languages, and the combination of participle and other auxiliary words, which can be called as an aspect conveys only aspectual meanings (Serebrennikov, 1958). The author to some extent contradicted himself. To be an aspect this phenomenon should have the aspect meaning, if it has the aspect meaning it should have the aspect expression.

Considering the problem of the aspect of the Turkic verbs, A. Scherbak (1981) wrote that 'there is no need to prove that the aspect is not an autonomous grammatical category. It is sufficient to note that the aspect does not have 'own' means of expression'. 
All verb categories have never had their own planes of expression, they function in a single continuum of expression. This situation was not accepted by linguists at that time. Unfortunately, it is not still perceived.

- The second thesis that there is the aspect category with its own peculiarities, it was created by tense or mood.

The absence of the aspect category in Turkic languages is compensated not only by the rich system of tense, but also by the presence of a widely developed Aktionsart, which are usually taken for the types of aspects in the Turkic languages' (Tikhonov, 1964).

Each category of the verb has its own discrete meaning, it is impossible to substitute the aspect category by other verb category as Tense and Aktionsart with its obscure status. They have their own functions. The aspect as an independent category may be or may be not, there is no third.

'In Turkish languages the verb is indifferent to the perfect or non-perfect actions. Aspectual shades can have separate temporal forms, as well as special complex verbs, the specific characteristics of which are given by auxiliary verbs' (Amirova).

Perfect and non -perfect actions are expressed on the basis of verbs, if the verb stem is indifferent, in that case there are no perfect and non -perfect aspects, because they are conveyed thanks to the verbs. Turkic verbs are very sensitive to any manifestations of actions, because it has six categories, including the aspect category (objectively verbs of all languages have this category, because the verb seme generates it, it is denied subjectively), which are ready to express everything, concerning to different properties of actions.

The actions are only changed according to the tense. In other words, the tense category expresses tense and aspect in Kazakh, Kyrgyz and Uzbek languages (Nur-makhanov, 1971). M. Tomanov who compared Kazakh, Uzbek, and Bashkir and Yakut languages said that 'the verb in the indicative mood is changed only according to the tense in the given languages' (Tomanov, 1992).

The role of tense is greatly exaggerated in diachrony, and in synchrony.

'Tense category only localizes and fixes actions on time line....' (Kakzhanova, 2015).

According to L. Johansson's (1999) opinion, there is the aspect category in Turkic languages, he came to conclusion, that 'Kipchak-Turkic languages have three types of operators. One aspect signals an intraterminal perspective, which includes events within its external borders. Another kind of signal in the postterminal viewpoint provides an event at a point after its corresponding completion time. The intraterminal (intraterminals) usually includes items called 'progressive', 'real', 'non-perfect', while postterminals include so-called 'result', 'statics' and 'perfect' events'

- Some linguists wrote about the creating role of the mood in forming of the aspect category.

'The aspect category is formed by mood in Turkic languages.... Mood denotes an action that is perceived as real; it expresses an action in the present, past or future tenses in positive negative aspects, as well as in aspects of possibility or impossibility. Present and past tenses are general concepts, each of which contains aspects' (Kononov, 1941). As it is seen, the category of the aspect does a complex path for realization itself here, at first the action turns into a mood, then into the category of tense, then it turns into the aspect category. The categories of the verb do not act in sequence they act simultaneously.

For example, aityp ketti (had said)

- aspect -perfect

- tense-past

- indicative mood

- active voice

All verb category meanings are expressed simultaneously in a single continuum of expression (Kakzhanova, 2015)

Turcologists paid attention to the other peculiarities of verbs, which express the existing of the aspect category as a conjugation 'the verb is conjugated according to the tense and aspect. The verbs are divided into several forms. They are made with the help of the adding affixes. The given forms demonstrate when and how actions are completed' (Dyrenkov, 1941). Conjugation is inherent to the person category and it conjugates verbs, it means, that the verbal categories (aspect, tense, voice, and mood) will be conjugated with their verb basis together.

- The language means of conveying of the aspect category in the Turkic languages. 
Turkic languages refer to agglutinative languages it means that these languages express language phenomena by adding postfixes than prefixes. But the aspect category is expressed by either analytical and synthetic ways (Kakzhanova, 2015).

A.I. Kharisov (1944) in his work "Category of verbal aspects in the Bashkir language wrote that 'aspect category is formed analytically, i.e. from the combination of the main verb, exclusively in the form of gerund with functional auxiliary verbs; affixively, i.e. by attaching certain affixes to the basis. The same opinion has D.M. Nasilov (1989), 'in the Turkic and Mongolian languages, biverbal structures are very common ' gerundive + an auxiliary verb' with a wide range of meanings'.

'In Turkic languages, the verb category includes a voice, aspect, mood, tense, number and a person, but they are expressed to a large extent in an original way, agglutinatively postpositionally, ie.with auxiliary verbs and suffixes (of some aspect category)' (Bogorodisky, 1953).

Many Turkologists stressed that the aspect category is expressed with the help of auxiliary verbs and gerunds, but the aspect category has no its own means of expression, it functions in a single continuum of expression with other verb categories.

B. N. Bogorodcky (1953) was right when he wrote about 'the verbs categories (means the Turkic languages) are the same as in Russian language'. Verb categories are the same not only in Kazakh and Russian languages, but also in all languages, but they express them differently, because there are hundred and hundred languages with their own structures and synergy.

N.K. Dmitriev (1948), considering the Kumyk verbal aspect, noted that 'the Turkic aspects are more diverse in meaning, but less in forms; so, from some verbs one aspect is formed, from others are others. Such situations as in Russian, when the aspect concept passes through all the content of the verb (in all moods and tenses), Kumyk language does not know. Because they are different languages in spite of they belong to synthetic languages, one is agglutinative, another is inflective and they are not comparable'.

- There are different opinions about the number of aspects.

'There are three aspects: perfect, imperfect and multiple aspects in theBashkir language (Dmitriev, 1948). According to G.Sh. Sharipov's opinion (1958) there are the beginning, lasting and perfect aspects in the Uzbek language and the perfect aspect combines with the combination of auxiliary verbs with the verbal gerund form of the main verbs'. 'There are three aspects: perfect, continuous and indefinite aspects in the Kazakh language (Sauranbaev, 1971), two aspects: perfect and non-perfect aspects in the Kazakh language were given by Uyukbaev I.

Practically turkologists considered that there were more aspects that it was in traditional aspect category: perfect and non-perfect. Nevertheless, this is not the limit.

\section{Results}

The review of studies of Turcologists demonstrates that there is a large palette of opinions on the category of aspect in diachrony in the Turkic languages. The proposed opinions and ideas on the verbal aspect theories in Turkic languages are not free from various contradictions and inconsistencies. It should be noted that every linguist understands the category of aspect in its own way, there is no a holistic theory for this category.

Since the Turkic languages are from the same group, they have a single matrix, a single structural organization with small internal divergences within the common matrix. When searching for the category of aspect in Turkic languages, the scholars were guided by the postulates of the traditional theory of the aspect, created on the basis of the means of the Slavic languages, in spite of that theories should be universal, but there was a conceptual confusion in traditional aspect theory, it will the theme of the other article.

The dominated ideas of Turcologists are:

- there is no the aspect category in the Turkic languages, it was stated directly and in many cases indirectly;

- there is an 'dependent' aspect category by tense, the aspect category as 'dependent' category either it was created by tense or mood, in general, there is no total denying the existence of the aspect category; 
- there is an extensive system of tenses, with the help of which, the aspect can be expressed if it is necessary;

- the verb categories function in isolation in sequence and they express their function uncoordinatedly, in spite of their functioning simultaneously;

- the aspect category is expressed analytically;

- the number of aspects are three instead of two: perfect and non-perfect as in the traditional aspectology; aspects;

- they are the perfect, imperfect and multiple aspects or the beginning, lasting and completed

The rhetorical question arises if the Türkic languages had the aspect, why there is still no official category of the aspect in the Kazakh language and it is considered temporal? When was it lost?

\section{Conclusion}

It is necessary to accept unjustly ignored the aspect category in the Turkish languages. The aspect category is not a secondary category, it is the center of proposition of sentences. The absence of even an insignificant linguistic category in the morphology of any language, and here we are talking about the category of the aspect expressing the proposition of sentences, makes the language flawed, not mature and undeveloped in the classification of languages from the standpoint of social and scientific opinion and makes it difficult to study, since there is no information about this phenomenon.

\section{References}

Amirova - Amirova Z.G. Kategorii vida i aspekta v indoevropeiskikh i tyurkskikh yazykakh [Categories of species and aspect in Indo-European and Turkic languages]. Kazakhskii natsional'nyi pedagogicheskii universitet imeni Abaya.

Bogorodisky, 1953 - Bogoroditskii V.A. (1953). Vvedenie v tatarskoe yazykoznanie v svyazi s drugimi tyurkskimi yazykami [Introduction to tatar linguistics in connection with other turkic languages]. Kazan', Tatgosiedat, P. 170.

Dmitriev, 1948 - Dmitriev N.K. (1948). Grammatika bashkirskogo yazyka [Grammar of the bashkir language]. M. L., Izd-vo AN SSSR, P. 196.

Dyrenkov, 1941 - Dyrenkova N.P. (1941). Grammatika shorskogo yazyka [Grammar of the shor language]. Moskva.

Hurmakhanov, 1971 - Nұrmakhanova Ә.N. (1971). Tүrki tilderiniң salystyrmaly grammatikasy», Almaty.

Kakzhanova , 2015 - Kakzhanova F.A. (2015). Kategoriya vida v kazakhskom yazyke i ee podvidy [Category of species in the Kazakh language and its subspecies]. Karaganda. 2015. P. 185.

Kharisov, 1940 - Kharisov A.I. (1940). Grammatika kumykskogo yazyka [Grammar of the Kumyk language].M. L. P. 140.

Kononov, 1941 - Kononov A.N. (1941). Grammatika turetskogo yazyka [Grammar of the Turkish language]. Moskva.

Nasilov, 1989 - Nasilov D.M. (1989). Problemy tyurkskoi aspektologii [Problems of turkic aspectology]. Aktsional'-nost'. L.: Nauka.

Sauranbaev, 1982 - Sauranbaev N.T. (1982). Қаzақ til biliminiң problemalary. Almaty. Izd: Nauka, pp. 125-175.

Serebrennikov, 1958 - Serebrennikov B.A. (1958). Problemy glagol'nogo vida v Tyurkskikh yazykakh [Problems in the verb form in Türkic languages]. Kn. Voprosy grammatiki tyurkskikh yazykovyu Alma-Ata.

Sharipov, 1958 - Sharipov S. (1958). Kategoriya glagol'nogo vida v azerbaidzhanskom yazyke [Category of the verbal species in the Azerbaijani language]. M., P. 10, 15.

Sherbak, 1981 - Shcherbak A.M. (1981). Ocherki po sravnitel'noi morfologii tyurkskikh yazykov (glagol) [Essays on comparative morphology of Turkic languages (verb)]. Leningrad «Nauka». 
Tikhonov, 1964 - Tikhonov A.N. (1964). Sushchestvuet li kategoriya vida v tyurkskikh yazykakh? [Is there a category of species in Turkic languages?]. Aktual'nye voprosy sovremennogo yazykoznaniya i lingvisticheskoe nasledie E.D.Polivanova. Mate rialy konferentsii. T. 1. Samarkand. Tomanov, 1992 - Tomanov M. (1992). TYrki tilderiniң salystyrmaly grammatikasy, Almaty. Uyukbaev, 1958 - Uyukbaev I. (1958). Voprosy Grammatiki Tyurkskikh yazykov [Questions of Grammar of the Türkic languages]. Alma-Ata: Izd-vo Akademii Nauk Kazakhskoi SSR. pp. 66-77.

Yuldashev, 1955 - Yuldashev A.A. (1955). Kategoriya glagol'nogo vidav bashkirskom yazyke [Category of the verbal form in the bashkir language]. Sb. Voprosy grammaticheskogo stroya $\mathrm{v}$ bashkirskom yazykeyuMyu , Izd-vo: AN SSSR. P. 365.

Johanson, 1999 - Johanson L. (1999). Typological notes on aspect and actionality in Kipchak Turkic. Studies in language companion series Tense-Aspect, Transivity and Causativity edited by W. Abraham, L. Kuliko. University of Groningen. 